\title{
Treatment of Cultural Heritage Content in the Subject Social Studies in Primary School
}

\author{
Polona Jančič, Vlasta Hus \\ Faculty of Education, University of Maribor, Maribor, Slovenia \\ Email: polona.jancic1@um.si,vlasta.hus@um.si
}

How to cite this paper: Jančič, P., \& Hus, V. (2018). Treatment of Cultural Heritage Content in the Subject Social Studies in Primary School. Creative Education, 9, 702-712.

https://doi.org/10.4236/ce.2018.95052

Received: March 6, 2018

Accepted: April 20, 2018

Published: April 23, 2018

Copyright (๑) 2018 by authors and Scientific Research Publishing Inc. This work is licensed under the Creative Commons Attribution International License (CC BY 4.0).

http://creativecommons.org/licenses/by/4.0/

\begin{abstract}
Presented research was conducted to analyse the representation and treatment of cultural heritage content in Social Studies classes at the elementary level of primary school. 68 Social Studies lessons in primary schools in the Republic of Slovenia were observed and analysed. Cultural heritage is part of the identity of every nation. Therefore, it is of great importance that even youngest students in primary schools are acquainted with it. The content of cultural heritage can be dealt with in a number of subjects at the elementary school level. Focus of the research was treatment of cultural heritage in Social Studies in $4^{\text {th }}$ and $5^{\text {th }}$ grade of Slovene primary schools. Results showed that in the half of the observed lessons the content of the cultural heritage was integrated into the lesson. Great majority of teachers discussing the content of cultural heritage put the main focus on knowledge. For the teaching of cultural heritage content, the didactic strategies inquiry-based learning and problem-based learning were mostly used.
\end{abstract}

\section{Keywords}

Cultural Heritage, Lesson, Primary School, Social Studies, Teaching

\section{Introduction}

Cultural heritage is part of the identity of every nation, and even youngest students need to be encouraged to preserve it. It is important that they try to understand the importance of cultural heritage, and the connection with the contemporary and responsible role of each individual in fostering and preserving it (Kostović-Vranješ, 2015). Among other things, school and teachers can also contribute to greater awareness of the importance and preservation of cultural heritage. The role of school and teacher is to encourage students to learn about 
different cultures, while preserving their national identity, their culture, social, moral and spiritual heritage (Čukelj, 2009).

The content of cultural heritage can be dealt with in a number of subjects at the elementary school level. In the greatest extent and most explicitly is the content of the cultural heritage recorded in the curriculum for Social Studies. The subject Social Studies is present in the fourth and fifth grades of primary school, and together encompasses 175 lessons. The basis for planning and conducting the teaching of each subject is the curriculum, approved by the Council of Experts of the Republic of Slovenia for General Education. The revised curriculum for the subject was published in 2011 by the Ministry of Education and Sport of the Republic of Slovenia in cooperation with the National Education Institute of the Republic of Slovenia (Budnar, Kerin, Umek, Raztresen, \& Mirt, 2011). The subject Social Studies upgrades and expands the objectives, content and activities that students learn in the first three years in the subject Environmental Studies. It includes objectives in the fields of geography, sociology, history, ethnology, psychology, economics, politics, ethics, aesthetics, ecology, etc. The objects are intertwined and interconnected. The focus of the subject is to learn about the relations between the individual, the society and the natural environment (Budnar et al., 2011).

The content sets that we deal with in the subject Social Studies are: People in society (I in community, family, children's rights, social issues), People in space and People in time (spatial orientation and cartography, hometown, home landscape, traces of the past, Slovenia-location and characteristics, historical development, the state of Slovenia). The content of the cultural heritage can be addressed in most of the content sets. The content of the cultural heritage is explicitly written in the learning objectives of the subject, where students:

- Evaluate the arrangement of the hometown in terms of different needs of people, protection of the environment, and natural and cultural heritage $\left(4^{\text {th }}\right.$ grade);

- Get to know the past of the hometown/home region through the lives of people and compare it with today's life ( $4^{\text {th }}$ grade);

- Get to know the natural and cultural heritage of the hometown/home region and understand why we need to take care of it ( $4^{\text {th }}$ grade);

- Assess how to protect and preserve natural and cultural environment $\left(5^{\text {th }}\right.$ grade);

- Learn about and outline some of the Slovenian characteristics (features), specialties and elements that shape national identity, and natural and cultural heritage $\left(5^{\text {th }}\right.$ grade $)$; and

- Develop a positive attitude towards tradition, and understand the importance of preserving it (folk customs and habits, cultural monuments, etc.) (5 $5^{\text {th }}$ grade) (Budnar et al., 2011).

How the content of cultural heritage is taught-by which method, form and didactic strategy, depends on the objectives that teacher wants to achieve, on 
prior students' knowledge and abilities. Marentič Požarnik (2008) writes that the methods to be used should be appropriately combined according to the objectives of the subject, circumstances and students. The didactic recommendations contained in The Curriculum for the Subject Social Studies (Budnar et al., 2011) suggest that the knowledge for life and Environmental Studies should be the basic criteria for the quality of students' knowledge, the concretisation of learning objectives, and the choice of teaching methods at environmental topics of Social Studies. People with their everyday activities and decisions influence the natural and social environment. A stronger awareness of our connection with the environment and the knowledge of the effects of our behaviour on the environment are crucial for the future of students and society. Given that the curriculum of the subject is based on constructivist theory, it is to be expected that, in order to achieve learning objectives better, teachers will choose didactic strategies at which learners are active. Didactic strategies that can be used to teach cultural heritage content and where students are active are: inquiry-based learning, problem-based learning, experiential learning, project work and practical learning. According to Šteh (2004), when defining active learning, the aspect of mental activity as well as autonomy in the regulation of one's own learning should be taken into account. We can talk about active learning when most of the learning activities are carried out and regulated by students themselves. Even in the transmission of learning, students are active in some way, because they listen to the explanation and try to grasp it. There is, however, a danger that they are acquainted with the findings that are the result of someone else's cognitive path. Therefore, they do not go through the cognitive process themselves. The transmission approach is predominantly grounded in the transfer of the finished knowledge (Rutar Ilc, 2007). In particular, we can mention experiential learning that can be defined as learning that seeks to connect human sensory and emotional experience, thinking, analysing and acting into a whole. A key element of experiential learning is a learner whose knowledge is the product of personal involvement in the pedagogical process (Wurdinger \& Carlson, 2010). In the field of experiential learning it is necessary to include and implement all of its phases: planning, introduction, activities, analysis, summary, transfer and evaluation. Experiential learning connects a direct experience (experiencing), observing, learning and acting. All these elements form an inseparable whole. A complete personal experience is the most important in this method (Budnar et al., 2011). Last but not least, in teaching the content of cultural heritage it should be noted that the extent of time in history and time orientation can give students of this age ( $9-11$ years) quite a few problems. Therefore, The Curriculum for the Subject Social Studies (Budnar et al., 2011) proposes that the historical content should emphasize the acquisition of ideas about the past and the basic understanding of historical development. It is important that students derive from their own history of being 10 or 11 years old the history of their parents and grandparents (100 years). 


\section{Methodology}

\subsection{Purpose of the Study}

By observing Social Studies lessons we wanted to obtain information that would highlight the treatment of the content of cultural heritage in the subjects Social Studies in Primary school. As written on the Introduction, it is important that even youngest students are encouraged to recognize and in time preserve cultural heritage. Since for some students' primary school is first organized formal education they are enrolled in, we were focused on primary school. After considering and studying curriculums for elementary level of primary school we choose Social Studies school subject as the one with more opportunities to teach and discuss cultural heritage content as in other school subject.

In observed Social Studies lessons we were interested:

- if cultural heritage content was treated;

- if there were any statistically significant differences in treatment of cultural heritage content in regards to the grade;

- if there were any statistically significant differences in treatment of cultural heritage content in regards to the address content set;

- what was teachers' main focus when discussing cultural heritage content;

- which didactic strategy was used in Social Studies lessons in which cultural heritage was treated.

\subsection{The Basic Research Method}

Descriptive and a non-experimental empirical method of pedagogical research was used in the study.

\subsection{Sample}

The convenience sample of the observed Social Studies lessons consist of 68 as shown in Table 1. 35 Social Studies lessons were observed in the $4^{\text {th }}$ grade and 33 Social Studies lessons in the $5^{\text {th }}$ grade.

\subsection{Data Collection}

Data was collected by observing the lessons, i.e. by observing the performance of the teachers at the lessons. Observation protocol was prepared; in which it was necessary to indicate whether a teacher addressed the content of cultural heritage at the lesson or not. At those lessons where teachers dealt with the content

Table 1. Number (f) and structural percentage (f\%) of the observed Social Studies lessons per grade.

\begin{tabular}{cccc}
\hline Grade & $\mathrm{f}$ & $\mathrm{f} \%$ \\
\hline $4^{\text {th }}$ grade & 35 & 51.5 \\
$5^{\text {th }}$ grade & 33 & 48.5 \\
Total & 68 & 100.0 \\
\hline
\end{tabular}


of cultural heritage, the observation was further directed towards the concrete content that the teacher dealt with, what was most emphasis put on, and the didactic strategy used. We chose Social Studies direct classroom observations, since this is a quantitative method of measuring classroom behaviors. The data that is collected from this procedure focuses on the frequency with which specific behaviors or types of behavior occurred in the classroom and measures their duration. Our focus was on following and measuring cultural heritage content representation and treatment. The data were obtained in March 2017 and partly in the first week of April 2017.

\subsection{Data Analysis}

Collected data was analysed with SPSS statistical computer program. For data processing, we used basic descriptive statistics, frequency distribution, and a non-parametrical Chi-Square test for independence. The difference between the groups was statistically significant if the risk level for the validity of the zero hypothesis was less than 5\% $(\mathrm{p}<0.05)($ Cramer \& Howitt, 2004; Field, 2013).

\section{Results}

\subsection{The Addressed Content Sets from the Curriculum for the Subject Social Studies}

Table 2 shows which content sets from The Curriculum for the Subject Social Studies were addressed by the teachers in the observed Social Studies lessons. In order to gain basic information about lessons goals and possible connection to the culture heritage it was important for us to know the content set that was addressed in observed lessons.

Table 2. Number (f) and structural percentage (f\%) of the addressed content sets at the observed Social Studies lessons.

\begin{tabular}{ccc}
\hline Discussed content set & f & f\% \\
\hline Historical development & 20 & 29.4 \\
Hometown & 14 & 20.6 \\
Home landscape & 13 & 19.1 \\
Traces of the past & 10 & 14.7 \\
Slovenia - location and characteristics & 7 & 10.3 \\
I in community & 2 & 2.9 \\
Family & 1 & 1.5 \\
Spatial orientation and cartography & 1 & 1.5 \\
Children's rights & 0 & 0.0 \\
Cooperation in community & 0 & 0.0 \\
Social issues & 0 & 0.0 \\
The state of Slovenia & 0 & 0.0 \\
Total & 68 & 100.0 \\
\hline
\end{tabular}


Table 2 shows that in 68 observed lessons the majority of teachers addressed the content from the content set Historical development. This is followed by the content sets: Hometown, Home landscape, and Traces of the past. Content sets Children's rights, Community participation, Social Issues and The state of Slovenia were not addressed at any of the observed lessons.

\subsection{Treating Cultural Heritage Content}

From Table 3 it can be concluded that teachers addressed the content of cultural heritage at 29 observed Social Studies lessons. At 39 Social Studies lessons they did not address cultural heritage content.

Test of differences between the observed Social Studies lessons in regards to the grade was made and its results are presents in Table 4.

It is evident from Table 4 that considering the treatment cultural heritage content at the observed Social Studies lessons there are no statistically significant differences between teachers of $4^{\text {th }}$ and $5^{\text {th }}$ grade. Next the Table 5 presents the results of testing statistical differences of the treatment of cultural heritage content in regards to the treated content set.

Most of the teachers who addressed the content of cultural heritage at the observed Social Studies lessons discussed the content set Historical development. This is followed the content sets of Traces of the past, Home landscape, Homeland, and Slovenia-location and features. In the case of the teachers who did not deal with cultural heritage content, the main content set was Hometown. According to the calculations, although taking into account the smallness of the

Table 3. Number (f) and structural percentage (f\%) of Social Studies lessons in relation to the treatment of cultural heritage.

\begin{tabular}{ccc}
\hline Cultural heritage content treatment & f & f\% \\
\hline Yes & 29 & 42.6 \\
No & 39 & 57.4 \\
Total & 68 & 100.0 \\
\hline
\end{tabular}

Table 4. Result of the $\chi^{2}$ test of the treatment of cultural heritage content at the observed Social Studies lessons by the grade of teaching.

\begin{tabular}{|c|c|c|c|c|c|}
\hline \multirow[t]{2}{*}{ Grade } & & \multicolumn{2}{|c|}{$\begin{array}{c}\text { Treatment of cultural } \\
\text { heritage content }\end{array}$} & \multirow[t]{2}{*}{ Total } & \multirow{2}{*}{$\begin{array}{c}\text { Result of } \\
\chi^{2} \text { test }\end{array}$} \\
\hline & & Yes & No & & \\
\hline \multirow{2}{*}{$4^{\text {th }}$ grade } & f & 12 & 23 & 35 & \multirow{6}{*}{$\begin{aligned} \chi^{2} & =2.071 \\
p & =0.150\end{aligned}$} \\
\hline & $\mathrm{f} \%$ & 34.3 & 65.7 & 100.0 & \\
\hline \multirow{2}{*}{$5^{\text {th }}$ grade } & $\mathrm{f}$ & 17 & 16 & 33 & \\
\hline & $\mathrm{f} \%$ & 51.5 & 48.5 & 100.0 & \\
\hline \multirow{2}{*}{ Total } & $\mathrm{f}$ & 29 & 39 & 68 & \\
\hline & $\mathrm{f} \%$ & 42.6 & 57.4 & 100.0 & \\
\hline
\end{tabular}


Table 5. $\chi^{2}$ test result of the treatment of cultural heritage content in the observed Social Studies lessons with regard to the treated content set.

\begin{tabular}{|c|c|c|c|c|c|}
\hline \multirow[t]{2}{*}{ Content set } & & \multicolumn{2}{|c|}{$\begin{array}{c}\text { Treatment of cultural } \\
\text { heritage content }\end{array}$} & \multirow[t]{2}{*}{ Total } & \multirow[t]{2}{*}{$\chi^{2}$ test result } \\
\hline & & Yes & No & & \\
\hline \multirow{2}{*}{ I in community } & $\mathrm{f}$ & 0 & 2 & 2 & \\
\hline & $\mathrm{f} \%$ & 0.0 & 100.0 & 100.0 & \\
\hline \multirow{2}{*}{ Family } & $\mathrm{f}$ & 0 & 1 & 1 & \\
\hline & $\mathrm{f} \%$ & 0.0 & 100.0 & 100.0 & \\
\hline \multirow{2}{*}{ Spatial orientation and cartography } & $\mathrm{f}$ & 0 & 1 & 1 & \\
\hline & $\mathrm{f} \%$ & 0.0 & 100.0 & 100.0 & \\
\hline \multirow{2}{*}{ Hometown } & f & 3 & 11 & 14 & \\
\hline & $\mathrm{f} \%$ & 21.4 & 78.6 & 100.0 & \\
\hline \multirow{2}{*}{ Home landscape } & $\mathrm{f}$ & 5 & 8 & 13 & $\chi^{2}=13.626$ \\
\hline & $\mathrm{f} \%$ & 38.5 & 61.5 & 100.0 & $p=0.580$ \\
\hline \multirow{2}{*}{ Traces of the past } & f & 8 & 2 & 10 & \\
\hline & $\mathrm{f} \%$ & 80.0 & 20.0 & 100.0 & \\
\hline \multirow{2}{*}{ Slovenia-location and characteristics } & $\mathrm{f}$ & 3 & 4 & 7 & \\
\hline & $\mathrm{f} \%$ & 42.9 & 57.1 & 100.0 & \\
\hline \multirow{2}{*}{ Historical development } & $\mathrm{f}$ & 10 & 10 & 20 & \\
\hline & $\mathrm{f} \%$ & 50.0 & 50.0 & 100.0 & \\
\hline \multirow{2}{*}{ Total } & $\mathrm{f}$ & 29 & 39 & 68 & \\
\hline & $\mathrm{f} \%$ & 42.6 & 57.4 & 100.0 & \\
\hline
\end{tabular}

sample, we can conclude that there are no statistically significant differences in the treatment of cultural heritage content in Social Studies with respect to the addressed content set. As an exciting feature we can highlight 20 lessons at which the content set Historical development was discussed. In $50 \%$ of these lessons the teachers included cultural heritage content, while in the other $50 \%$ it was not included.

In the Social Studies lessons in which cultural heritage content was treated we continued to observe what was teachers' main focus when discussing cultural heritage content.

From Table 6 we can see that at the observed lessons a great majority of teachers discussing the content of cultural heritage put the main focus on knowledge. At five observed lessons the teachers paid the most attention to experiencing and feeling. In only two lessons the teachers focused on the development of students' skills.

Finally, we observed which didactic strategy was used in Social Studies lessons in which cultural heritage was treated and results of representation of didactic strategies are presented in Table 7. 
Table 6. Number (f) and structural percentage (f\%) of the observed lessons of the discussed cultural heritage content with elements that teachers focused on.

\begin{tabular}{ccc}
\hline Answers & f & f\% \\
\hline Knowledge & 22 & 75.9 \\
Experiencing and feeling & 5 & 17.2 \\
Skills & 2 & 6.9 \\
Values and beliefs & 0 & 0.0 \\
Other & 0 & 0.0 \\
Total & 29 & 100.0 \\
\hline
\end{tabular}

Table 7. Number (f) and structural percentage (f\%) of the didactic strategies used at the observed Social Studies lessons with treatment of cultural heritage content.

\begin{tabular}{ccc}
\hline Didactic strategy & f & f\% \\
\hline Inquiry-based learning & 7 & 24.1 \\
Problem-based learning & 7 & 24.1 \\
Experiential learning & 5 & 17.2 \\
Project work & 4 & 13.8 \\
Practical work & 3 & 10.3 \\
Other & 3 & 10.3 \\
Total & 29 & 100.0 \\
\hline
\end{tabular}

At the question of the most used didactic strategy, as it can be seen from Table 7 , the teachers most frequently used inquiry-based learning and problem-based learning. Some teachers used experiential learning and project work. Three teachers used practical work, which coincides with the answers in Table 6, where we found that only two teachers devoted most of their attention to developing skills. In the category "Other" we found that three teachers used frontal instruction in combination with a workbook. According to the results of the observation we found that all didactic strategies were represented in the observed lessons, so we can conclude that teachers use different didactic strategies in cultural heritage teaching.

\section{Discussion}

By observing the Social Studies lessons, representation of cultural heritage content in randomly selected lessons of Social Studies was analysed. The results showed that at the observed lessons most of the teachers addressed the content from the section Historical development. This is followed by the content sets Hometown, Home landscape, and Traces of the past. Content sets Children's rights, Participation in community, Social issues, and The state of Slovenia were not addressed at any of the observed lessons. At 29 observed lessons of Social Studies we noticed the treatment of cultural heritage. At 39 lessons the cultural 
heritage was not addressed. Most of the teachers who discussed the contents of cultural heritage in the observed lessons of Social Studies addressed the contents of Historical development. This is followed by the contents of Traces of the past, Home landscape, Hometown, and Slovenia-location and characteristics. The results thus presented the situation from the Curriculum for Social Studies (Budnar et al., 2011), because also in it, as in the above-listed content sets where we did not notice the treatment of cultural heritage content, we cannot find the stated goals that would explicitly address the contents of cultural heritage. In view of the results, given the small size of the sample, we can conclude that there are no statistically significant differences in the treatment of cultural heritage contents in the subject Social Studies in regards to the content sets. Those teachers who discussed the contents of cultural heritage at the observed lessons of Social Studies combined the treatment of several cultural heritage aspects into one lesson. The majority of teachers devoted most of their attention to knowledge when dealing with the content of cultural heritage. At five observed lessons teachers paid most attention to experiencing and feeling. At only two lessons teachers focused on the development of students' skills.

For the content of the cultural heritage, teachers most frequently used inquiry-based learning and problem solving. Some teachers used experiential learning and project work. Therefore, the use of selected didactic methods was in accordance with special didactic recommendations, which for the teaching of Social Studies proposes methods and forms of work in which learners are active. Inquiry-based learning can be defined as a special didactic strategy of scholarly acquisition which introduces elements of scientific work into teaching, and consequently enables simultaneous learning of the content and the process itself (Blažič et al., 2003). Inquiry-based learning is a multi-faceted concept and ranges from viewing literature on the World Wide Web to playing with various construction collections (Razpet, 2008). In Social Studies teaching, the didactic strategy of inquiry-based learning is especially suggested when addressing the content set People in time. Learners are expected to carry out as much concrete activities as possible, such as fieldwork by observing the surroundings of the school, a town and its historical features, or visiting a museum, etc. (Budnar et al., 2011). At problem-based learning, learners are placed in front of a real problem, which makes sense for them, since problem-based lessons are directed to solving different problems. So basically, problem-based lessons are very similar to research work, with the difference that problem-based earning is centred on a particular problem. Strmčnik (2003) defines problem-based learning as the highest didactic strategy. The starting point of problem solving is a problem situation, which is extremely motivational for students. It is important that learners when solving the problem call into their awareness previous experience and knowledge. With the help and guidance of the teacher, they then look for an appropriate solution to the problem (Ivanuš Grmek \& Hus, 2006). Zabukovec (2007) emphasizes another important element of problem-based lessons, i.e. its 
psychological motivational power. If a student is excited about and interested in a problem, they want to find a solution to it. Thus they do not perceive problem situations only rationally, but also experience them, which makes it easier for them to identify with the problem.

\section{Conclusion}

Especially with the content of cultural heritage, it is important that students identify with it to understand why it is important and, consequently, know how to preserve it, and ultimately want to do so. Even though, sample of observed lessons teachers is not representative, it provides basics for planning broader research. There are also some cautions related to the use of structured observation techniques which can be structured into three subsections: theoretical and epistemological criticisms, methodological concerns and pragmatic concerns (Delamont, \& Hamilton, 1986). In order to gain even more comprehensive study of representation and treatment of cultural heritage contents in Social Studies lessons combining both - qualitative and quantitative research methods is advised.

As results showed that in only the half of the observed Social Studies lessons the content of the cultural heritage was integrated into the lesson this result can also be used as a guideline in planning future teachers' education. As a first step in improving future primary teachers' knowledge on treatment of cultural heritage content in Social Studies, we planned and defined curriculum for an optional subject for students of Educational Faculty in primary education courses.

As 2018, being a European year of cultural heritage, is a great opportunity to start and develop additional research on cultural heritage. This year is expected to be full of different projects and celebrations all over Europe, designed to inspire public interest for cultural heritage among adults and children. Educators can use this year's celebrations as an opportunity to additional integration of cultural heritage content treatment.

\section{References}

Blažič, M., Ivanuš Grmek, M., Kramar, M., \& Strmčnik, F. (2003). Didaktika. [Didactics.] Novo mesto: Visokošolsko središče, Inštitut za raziskovalno in razvojno delo.

Budnar, M., Kerin, M., Umek, M., Raztresen, M., \& Mirt, G. (2011). Učni načrt. Program osnovna šola. Družba. [Primary School Curriculum for Social Studies]. Ljubljana: Ministrstvo za šolstvo in šport, Zavod RS za šolstvo.

Cramer, D. \& Howitt, D. L. (2004). The SAGE Dictionary of Statistics: A Practical Resource for Sudents in Social Sciences. London: SAGE Publications Ltd. https://doi.org/10.4135/9780857020123

Čukelj, Z. (2009). Mogućnosti stjecanja znanja i spoznaja o prirodnoj i kulturnoj baštini u osnovnim školama Republike Hrvatske. Socijalna ekologija [Social Ecology], 18, 267-288.

Delamont, S., \& Hamilton, D. (1986). Revisiting Classroom Research: A Cautionary Tale. In M. Hammersley (Ed.), Controversies in Classroom Research. Philadelphia: Open University Press. 
Field, A. (2013). Discovering Statisctics using IBM SPSS Statistics ( $4^{\text {th }}$ ed.). London: SAGE Publications Ltd.

Ivanuš Grmek, M., \& Hus, V. (2006). Odprti pouk pri predmetu spoznavanje okolja. Sodobna pedagogika [Journal of Contemporary Educational Studies], 57, Ljubljana: Zveza društev pedagoških delavcev Slovenije.

Kostović-Vranješ, V. (2015). Baština-polazište za promicanje odgoja i obrazovanja za održivi razvoj. Školski vjesnik [Journal for Pedagogic Theory and Practice], 64, 439-452.

Marentič Požarnik, B. (2008). Konstruktivizem na poti od teorije spoznavanja do vplivanja na pedagoško razmišljanje, raziskovanje in učno prakso. [Constructivism on the Way from Epistemological Theory to Educational Thinking, Research and Teaching Practice.]. Sodobna pedagogika [Journal of Contemporary Educational Studies], 59, 28-51.

Razpet, N. (2008). Zgodnje uvajanje v raziskovalno učenje. In Udovič (Ed.), Sodobne strategije učenja in poučevanja [Modern Strategies of Learning and Teaching] (pp. 197-208). Koper: Pedagoška fakulteta.

Rutar Ilc, Z. (2007). Aktivno učenje in procesni pristop-pot do konceptualnega razumevanja. In Kurikul kot proces in razvoj [Curriculum as a Process and Development] (pp. 109-122). Ljubljana: Zavod RS za šolstvo.

Šteh, B. (2004). Koncept aktivnega in konstruktivnega učenja. In B. Marentič Požarnik (Ed.), Konstruktivizem $v$ šoli in izobraževanje učiteljev [Constructivism in School and Teacher Education] (pp. 149-164). Ljubljana: Center za pedagoško izobraževanje filozofske fakultete.

Strmčnik, F. (2003). Didaktične paradigme, koncepti in strategije. [Didactics Paradigms, Concepts and Strategies]. Sodobna pedagogika. [Journal of Contemporary Educational Studies], 54, 80-93.

Wurdinger, S. D., \& Carlson, J. A. (2010). Teaching for Experiential Learning: Five Approaches That Work. Lanham, MD: Rowman and Littlefield Education.

Zabukovec, M. (2007). In M. Budnar et al. (Eds.) Družba 5.razred-Načrtovanje, poučevanje, učenje, ocenjevanje (str. 22-31). Ljubljana: Zavod RS za šolstvo. 